\title{
An Action Research Study on Improving Seventh Standard Students' Creative Writing Skill in English
}

\author{
Anjali Parida, Puspalata Rout and Bijay Kumar Swain* \\ Pre-service student teacher, DIET, Balasore, Remuna, Odisha-756019 \\ *Teacher Educator, DIET, Balasore, Remuna, Odisha-756019
}

\begin{abstract}
One of the most vital elements of education and literacy is Language. Learning a language is similar to swimming and riding a bicycle. Thus the present action research is aimed to improve the writing skill of the $7^{\text {th }}$ standard students creatively in an Elementary school. A total sample of 15 students' from the same grade was chosen for the study. The baseline assessment was carried out to explore the pre-intervention writing skill score of the students prior to the intervention cycle. Later, intervention and writing skill support strategies were carried out for six weeks. In the end, post-test was carried out to explore the differences between the pre- and post-test score of the students. The finding of the present work is suggested that writing skill of the students has been increased up to a satisfactory level. The creativeness of the writing skill was also increased.
\end{abstract}

Keywords: Creative writing, Action research, Essay writing, English, Language

\section{INTRODUCTION}

One of the most vital elements of education and literacy is Language. Learning a language is similar to swimming and riding a bicycle. We learn them by practice and use. There are four basic skills of language learning. These are listening, speaking, reading and writing. Among these four languages skill, listening and reading are receive skill and speaking and writing are productive skills. Writing is the final skill in the hierarchy of language skills. Its efficiency and commands come with the mastery in receive and productive skills. From our early generation to till now the productive skills of language are in main focus of which writing is the most preferred outcome expected of students, in all over world. This is possible only in schools where the students are required to master in good writing compositions (Nasir et al., 2013).

Creative writing can technically be considered any writing of original composition. In this sense, creative writing is a more contemporary and process-oriented name for what has been traditionally called literature, including the variety of its genres. Creative writers typically decide an emphasis in either fiction or poetry, and they usually start with short stories or simple poems. They then make a schedule based on this emphasis including literature classes, education classes and workshop classes to strengthen their skills and techniques. Creative writing helps to involve in extracurricular writing-based activities, such as publishing clubs, school-based literary magazines or newspapers, writing contests, writing colonies or conventions, and extended education classes.

Creative writing is usually taught in a workshop format rather than seminar style or in normal classroom transaction. In workshops students usually submit original work for peer critique. Students develop a writing method through the process of writing and re-writing. Generally the students of higher classes' became efficient in generating and organizing creative ideas. Writing process is one of the most adopted teaching model which helps in developing writing skills in the balanced literacy approach (Zampardo, 2008).

Being an ability, writing can be improved by learning through repetition. When teacher will well aware of the writing process, this will help in appropriate teaching strategies and that will also improve the writing abilities of students in education environment (Oberman and Kapka, 2001). In writing process, there are five stages i.e, Prewriting, Drafting, Revising, Editing and Publishing. If the writing process of any stage will skip, then students will not improve their creative thinking power. Learning the writing process is important for the students as it enables students to express their thoughts, knowledge and feelings efficiently. When students feel more competent in their writing process, then they will express themselves efficiently (Creswell, 2008; Smith, 2000). According to Brookes and Marshall (2004), imagination and originality are valued more than the standardization of thought and truthfulness while characterizing creative writing. While assessing the student for creative writing, they are given space to construct the content. The main purpose is to evaluate their creative writing and cognitive skills. In order to write creatively, it is essential that the thoughts of the students' should not be restricted in a confined area. For creative writing, important pre-requisites are planning, organization and discovery of thought. If appropriate scope will not be provided to the students then they will not be able to maintain the originality of their creative work (Richards, 1990). In order to motivate the students to engage in 
creative writing exercises the facilitator should provide sufficient opportunities to the students to involve themselves in high order thinking and a regular habit of reading (Nasir et al., 2013). During practice teaching the researcher came to know that school students are lack of writing skills and the teachers don't seem to using a proper writing process too. Therefore, this study aimed at describing the difficulties pertaining to composition writing and strategies to develop writing abilities of the students to write creatively. Therefore, an attempt is made here in the form of an action research study on creative writing, to develop the vocabulary and use of correct Grammar skills and to develop the skill of creative writing of seventh standard students of Ramachandra Nodal UP School, Remuna, Balasore, Odisha.

\section{METHODOLOGY}

The researchers determined action research (experimental designing) for this study. During the research; a pre-test was done, interventions were made consistently and finally post- test was done. For this study, all students of Ramachandra Nodal Upper Primary School studying in Class-VII were taken as sample.

\section{Sampling method}

A sample of 15 students out of the population of all the students (22) of Class-VII was drawn and the sampling method was simple random sampling. The sample of 15 students was drawn from the population randomly by lottery method. First of all the names of the 22 students were wrote on separate slips of paper, fold those slips, mixed them thoroughly and then made a blind fold selection of 15 slips. The age group of these students varied from 11-14years. The students were talking English (neither fluently nor properly) with each other and others. Again, they were not able to write English in a proper manner, though they studied in seventh standard. In Odisha, the English of seventh standard is not high standard; still they were not able to write such English. Both pre-and post test was conducted during the study period in classroom, as the performance of the students was measurable.

\section{Measures}

Learning achievement test for English language composition was designed to collect the data about students' baseline status of composition proficiency and another similar genre paper was designed to explore the impact of intervention on the students, which was given at the end of the cycle completion as a post-test.

Pre-test: Composition test consisted of "Your Class Teacher" for pre-test. Then the students creativity was evaluate on the basis of different criteria such as spelling, punctuation, vocabulary, organization, Grammar, content quality and creativity. The pre -test identified the current level of writing skills of the students.

\section{Intervention}

The researchers planned to work on the incompetent writing skills of the students, which they noticed during their practice teaching. Later the research was conducted after discussing with the detail plan with the subject teacher and taking permission of the Headmistress of the concerned school. Again, a few strategies were laid down as intervention which consisted of various creative writing exercises. The students were asked to explain some pictures after providing list of vocabulary, having some dictionary in the class, updating the class word bank, and recommending students to use dictionary and word list frequently (Nasir et al., 2013). Then, Grammar was taught by activity based approach. A special interest was shown by the researcher in creative writing and the students were highly motivated by it and tried to give their extra efforts as well. The rules for sentence structure such as the subject, object and verb agreement were also verbally taught to the whole class. Intervention was carried out consequently for six weeks. After 15days, a post-test was taken to see what changes had taken place in the writing skills of the students.

\section{Post-test}

After intervention a post-test was done. In this test, five words, such as fair, line, interesting, shopkeepers and magic was given to the students and asked them to write an essay in ten sentences. During such work the researcher also asked them to write the title of the essay. Interestingly, 9 children's were written the name of the essay correctly, while four were haphazardly and rests two were written the same after discussing with their friends.

\section{RESULTS AND DISCUSSION}

The data collected by the researchers in pre-test and post-test was analysed. The scores were compared to obtain the difference between the two tests. The data analysis of pre-test (Table-1) and post-test (Table-2) revealed that the children mostly improved their creativity as the result was increased by $41 \%$. In all areas the improvement was noticed except a little bit. In spelling the post- test increased by $23 \%$, in punctuation the posttest increased by $12 \%$ whereas the text organized was upgraded by $11 \%$ and in Grammar the post-test was 
increased by $23 \%$. Such result was obtained because the teacher had focused on a regular intervention and children when given vocabulary are seemed to have shown prominent progress (Nasir et al., 2013). When the scores of these two tests were compared (Table-3), the difference was clearly visible. In content quality the posttest increased by $28 \%$ and in Vocabulary it was $21 \%$. The greatest improvement was shown in the areas of creativity $(41 \%)$ and content quality $(28 \%)$. This was due to the reason that a lot of reinforcements of new words were done. Writing practice was made very carefully. Children were made aware of the correct use of the words that were introduced by the researchers on regular basis. As a special interest was shown by the researcher in creating writing, the students were much motivated by it and tried to put in their extra efforts as well. The rules for sentence structure such as the subject, object and verb agreement were also taught by both verbally and activity based activity based approach to the class which contributed to the better results in the area of general English grammar and the text structure of the students. The development of creative writing among seven standard students is possible only by increasing their reading ability and thinking power. The researcher was given a lot of scope to the students' to think the subject matter in their own way. As the students were belonging to 12-13 age groups, the researcher also facilitates them at the time of their need.

Table 1: Result of class- VII students in writing essay before taking interventions

\begin{tabular}{|l|l|}
\hline \multicolumn{1}{|c|}{ Criteria } & Pre-test \\
\hline Spelling & 35 \\
\hline Punctuation & 33 \\
\hline Vocabulary & 42 \\
\hline Organization & 45 \\
\hline Grammar & 26 \\
\hline Content quality & 46 \\
\hline Creativity & 32 \\
\hline
\end{tabular}

Table 2: Result of class- VII students in writing essay after taking interventions

\begin{tabular}{|l|l|}
\hline \multicolumn{1}{|c|}{ Criteria } & Post-test \\
\hline Spelling & 43 \\
\hline Punctuation & 40 \\
\hline Vocabulary & 47 \\
\hline Organization & 50 \\
\hline Grammar & 32 \\
\hline Content quality & 59 \\
\hline Creativity & 45 \\
\hline
\end{tabular}

Table 3: Comparative score chart of Students Vocabulary Comprehension Tests.

\begin{tabular}{|l|l|l|l|l|}
\hline Criteria & Pre-test & Post-test & $\Delta$ & \% \\
\hline Spelling & 35 & 43 & 8 & 23 \\
\hline Vocabulary & 33 & 40 & 7 & 21 \\
\hline Punctuation & 42 & 47 & 5 & 12 \\
\hline Organization & 45 & 50 & 5 & 11 \\
\hline Grammar & 26 & 32 & 6 & 23 \\
\hline Content quality & 46 & 59 & 13 & 28 \\
\hline Creativity & 32 & 45 & 13 & 41 \\
\hline
\end{tabular}

In order to know the difference between the pre-test and post-test, t-test was applied and the value of mean score, standard deviation, $\mathrm{t}$-value was presented in the Table- 4 .

Table 4: Mean, Standard Deviation, Standard Error of Mean, $t$-value, degrees of freedom (df), and level of significance of the scores obtained from tests with respect to variable-performance

\begin{tabular}{|l|l|l|l|l|l|l|l|}
\hline Performance & N & Mean & SD & SEM & df & 't' & Level of Significance and its value \\
\hline Pre-test result & 15 & 3.8 & 3.74 & 0.97 & 14 & 3.92 & 2.3 at 0.05 level \\
\hline Post-test result & 15 & 3.8 & & & & & \\
\hline
\end{tabular}

The tabulated value of ' $t$ ' at 0.01 and 0.05 level of significant was 2.14 and 2.3 , respectively. Since the calculated t-value was more than the tabulated value at 14 degree of freedom, the difference between the average of pre-test score and post- test scores was significant. Hence it is clear that through different activity creative writing of students was developed. 


\section{CONCLUSION}

From the above discussion, it has been concluded that the intervention has been proved to be fruitful in most of the students, while some reflection is required for those who did not progress. The intervention proved to bring out significant improvement in enhancing the composition writing skills of the students. The findings of this research can be beneficial for the teachers of both elementary and secondary schools, pupil teachers and students. This may very helpful for the teachers to adopt suitable pedagogical process for improvement of writing skill of their students. It would be enjoyable and beneficial for those teachers who have direct contact with the students and they would be excited to witness a change. Basing upon the above discussion, the following might be suggested: every stage of the writing process should be studied and demonstrated by both, teachers and the students in order to develop the writing abilities (Nasir et al., 2013; Mak and Conium, 2008; Walker et al., 2005).

\section{ACKNOWLEDGEMENTS}

The researchers are thankful to the Principal, DIET, Balasore for helping us in conducting the study.

\section{REFERENCES}

[1]. L. Nasir, S. M. Naqvi, and S. Bhamani. (2013). Enhancing students' creative writing skills: An Action Research project. Acta Didactica Napocensia, 6 (2), 2013, 27-31.

[2]. B. Mak, and D. Coniam. Using wikis to enhance and develop writing skills among secondary school students in Hong Kong. System, 36(3), 2008, 437-455.

[3]. B. Walker, M.E. Shippen, P. Alberto, D.E. Houchins, and D.F. Cihak. Using the Expressive Writing program to improve the writing skills of high school students with learning disabilities. Learning Disabilities Research \& Practice, 20(3), 2005, 175-183.

[4]. I. Brookes, and M. Marshall. Good writing guide. New York: Harap Publishers Ltd, 2004.

[5]. J. Richards. New Trends in the Teaching of Writing in ESL/ EFL in Wang Z. (ed.) ELT in China. Papers Presented at the International Symposium on Teaching English in the Chinese Context, Foreign Language Teaching and Research Press, Beijing, 1990.

[6]. A. Özbek. The effect of a creative thinking programme on EFL students'attitudes towards their own creativity in writing. Yayımlanmamış yüksek lisans tezi, Gazi Üniversitesi, Eğitim Bilimleri Enstitüsü, Ankara, 2006.

[7]. D. Kapka, and D.A. Oberman. Improving student writing skills through the modeling of the writing process. Research Project, Saint Xavier University and Sky Light Professional Development Field-Based Masters Program. ERİC ED, 2001, 453536.

[8]. K.M. Zampardo. An examination of the impact of teacher modeling on young children's writing. Unpublished doctoral thesis. Oakland University, Michigan, 2008. (UMİ No: 3340069)

[9]. C.B. Smith. Writing instruction: Current Practices in the classroom, 2000 (ERIC Document Reproduction Service No: ED446338).

[10]. J.W. Creswell. Research design: Qualitative, quantitative, and mixed methods approaches. Sage Publications, Thousand Oaks, CA, 2008. 